\title{
Assessment of adaptive capacity to saltwater intrusion in the context of climate change in Dong Nai province to 2030
}

- Le Ngoc Tuan

University of Science, VNU-HCM

- Vu Thi Ngoc My

Institute of Meteorology Hydrology Oceanology and Environment

(Received on $4^{\text {th }}$ May 2016, accepted on $2^{\text {nd }}$ December 2016)

\begin{abstract}
This study aimed to evaluate the adaptive capacity (AC) to saltwater intrusion (SI) in Dong Nai province up to 2030 via 20 indicators. The research scope included 57 wards in Bien Hoa city, Long Thanh, and Nhon Trach districts where have been facing the SI. Results showed that in 2014, nearly $90 \%$ of investigated wards have $A C$ indices in the range of medium-low level, distributed in Bien Hoa (30), Long Thanh (15), and Nhon Trach (6). Forecasts to 2020 and 2030, the local AC indices to saltwater intrusion are increased: the mentioned number of $90 \%$ is gone down to about $88 \%$ and $60 \%$ in 2020 and
\end{abstract}

2030, respectively. Indicators need taken into concern to improve the local AC include: financial (budget, GDP), policy (support for people to cope with SI and climate change), agriculture (salt-tolerant seeds), aquaculture (brackish and saline water aquaculture), irrigation work (irrigation, SI prevention system), water storage, health, and education. Overall, in the period of 2014-2030, the AC of the investigated area has increased over the years, but most at the medium - low level. This is the challenge for governments and communities in responding to SI in the context of climate change.

Keywords: saltwater intrusion, adaptive capacity, adaptive capacity index, climate change

\section{INTRODUCTION}

In the context of the climate change (CC) increasingly going strong, rivers' flow has been greatly influenced, indirectly affecting the saltwater intrusion (SI), thereby, altering the water quality, affecting most of relevant activities in the riparian areas. Recently, many studies on $\mathrm{CC}$ consider SI as one of the most concern issues, especially in the estuaries and coastal areas [1-5].

Dong Nai province is in Dong Nai - Saigon river basin, despite the landlocked area (the nearest point from the sea is about $9 \mathrm{~km}$ ), but with the characteristics of water reserves distribution (approximately $20 \%$ in the dry season) and a semi-diurnal tide, rivers here are still at a high risk of SI. In recent years (monitoring data from 2007 to 2014), the salinization in Dong Nai province was negatively changed the salinity had increased significantly, especially from March to May. Thus, the SI in Dong Nai province is increasingly serious and should be concerned. Many studies on SI were carried out in the downstream Dong Nai river [69], however, mostly focused on assessing the salinization current, simulating and warning, etc. In other words, the vulnerability to SI in the context of CC has not been forecasted and fully assessed yet.

The adaptive capacity (AC) of a system can be basically resulted from human activities such as education, income, health, institutions, and

Trang 227 
technology [10]. Besides, natural elements of the system may also alter the AC. Some AC indicators are often used: management capacity $[11,12]$, budget [13], infrastructure [12, 14], human, etc. of the government, awareness [11, 12], income [11-13], coping experiences [13], access to information [11, 14], of communities. Accordingly, in this work AC indicators were divided into 2 groups: local government and communities. The analysis and evaluation of components forming adaptive capacity are important factor for identifying solutions. This is considered as one of the outstanding characteristics of the evaluation approach.

It is very important to assess completely vulnerability to SI in the context of $\mathrm{CC}$ of different regions or sectors - to be considered in the relationship among the level of exposure (E), sensitivity (S) and adaptive capacity (AC) [15]. That provides a basis for planning suitable policies, strategies, and coping measures in each specific condition, contribut to minimize risks, and ensuring the sustainable development of concerned socio-economic sectors. However, indicators used to assess vulnerability in general and each part (E, S, and AC) in particularly have not been detailed established. Accordingly, this study aims to evaluate the AC to SI in the context of CC in Dong Nai till 2030 by the index method (based on related indicators), detailed to communes/wards in the investigated areas (Bien Hoa city, Long Thanh and Nhon Trach districts), serving the vulnerability assessment to SI in the context of CC.

\section{METHODS}

(1) Literature review and data analytical method: Most of concerned data and materials (based on research objectives and indicators for AC assessment) were collected from specialized agencies, research institutes, universities, journals, etc. and then were synthesized and analyzed by Microsoft Excel software to serve this work.

(2) Sociological investigation method: The survey of adaptive capacity (awareness, attitudes, and behaviors of communities and local managers about SI and CC, management capacity of related sectors, etc.) was performed via questionaires in the riparian areas, including Bien Hoa city, Nhon Trach and Long Thanh districts. Respondents were residential communities (270 households), commune/ward/town authorities (57 Commune People's Committees), local managers (45 officers).

(3) Professional adjustment: this was applied in conjunction with the analytic hierarchy process (AHP) to identify AC indicators and calculate their weights. 30 experts from 17 prestigious universities, institutes, environmental and climate change research centers in the southern Vietnam participated in the survey.

(4) The analytic hierarchy process - AHP: this was used to calculate weights of $\mathrm{AC}$ indicators. Results of the survey experts' opinions were synthesized by the geometric average method. Priority weight of each indicator was resulted from the multiplication between its weight and the weight of the group that it belongs to. Professional adjustments were considered consistent when the consistency ratio $\mathrm{CR}$ is $\leq 0.1$.

(5) GIS method: was applied to extract data on the map, mapping the AC index to SI in order to visualize calculating results by the MapInfo 11.0 .

(6) Index method: The process of adaptive capacity assessment by index method is as follows:

- Identifying indicators.

- Determining the weight of each indicator.

- Collecting and calculating related figures; standardizing data in the scale of 0-100.

- Calculating adaptability index.

Trang 228 
- Mapping, analysis and evaluation.

$\mathrm{AC}$ indices were calculated based on standardized values of sub-indices $\left(\mathrm{AC}_{i}\right)$ and their weights $\left(\mathrm{w}_{A c i}\right)$ by the formula: $\mathrm{AC}=$ $\sum_{i=1}^{n} A C_{i} * W_{A C i}$ where $\mathrm{n}$ : number of component indicators; $\mathrm{AC}_{i}$ : standardized value of the $\mathrm{i}$ indicator; $\mathrm{W}_{A c i}$ : priority weights of the $\mathrm{i}$ indicator; AC: the synthetic adaptive capacity.

The AC values to SI were evaluated as presented in Table 1.

Table 1. Assessment scale of adaptive capacity

\begin{tabular}{|c|c|c|c|c|}
\hline Value & $\mathbf{0 - 2 5}$ & $\mathbf{2 5 - 5 0}$ & $\mathbf{5 0 - 7 5}$ & $\mathbf{7 5 - 1 0 0}$ \\
\hline AC & Low & Medium-low & Medium-high & High \\
\hline
\end{tabular}

\section{RESULTS}

\section{Indicators and weighted evaluation}

Indicators: By professional adjustment method as mentioned, indicators for evaluating adaptive capacity to SI in the context of CC was built as in Table 2 .
Calculation of indicators' weights: Based on experts' opinions, pairwise comparison matrices were established and the concerned weights were calculated, including weights of each component indicator and of each group. Priority weight of each indicator is presented in Fig. 1.

Table 2. The indicator for evaluating adaptive capacity for SI in the context of climate change

\begin{tabular}{|c|c|c|c|}
\hline \multicolumn{2}{|r|}{ Local government } & \multicolumn{2}{|r|}{ Communities } \\
\hline Code & Indicator & Code & Indicator \\
\hline AC.cq.1 & $\begin{array}{l}\text { The number of staff taking charge of } \\
\text { environmental resources }\end{array}$ & AC.cd.1 & $\begin{array}{l}\text { Awareness of communities of climate } \\
\text { change and SI }\end{array}$ \\
\hline AC.cq. 2 & $\begin{array}{l}\text { Awareness of managers of climate } \\
\text { change and SI }\end{array}$ & AC.cd. 2 & $\begin{array}{l}\text { Ability to access information when } \\
\text { occurring incidents (internet, TV, } \\
\text { cellphone etc.) }\end{array}$ \\
\hline AC.cq.3 & $\begin{array}{l}\text { Programs / plans to support the people } \\
\text { in SI field (information, financial, etc.) }\end{array}$ & AC.cd.3 & $\begin{array}{l}\text { Ability of clean water storage } \\
\text { (volume, time of use, etc.) }\end{array}$ \\
\hline AC.cq.4 & $\begin{array}{l}\text { The budget for coping with climate } \\
\text { change and SI incidents }\end{array}$ & AC.cd.4 & $\begin{array}{l}\text { The number of salt-tolerant crop } \\
\text { varieties }\end{array}$ \\
\hline AC.cq. 5 & $\begin{array}{l}\text { The number of salinity monitoring } \\
\text { stations }\end{array}$ & AC.cd.5 & $\begin{array}{l}\text { The proportion of salt-tolerant crop } \\
\text { area / total farmland area }\end{array}$ \\
\hline AC.cq.6 & $\begin{array}{l}\text { The proportion of agricultural land } \\
\text { supported by the salty preventing works }\end{array}$ & AC.cd.6 & Diversity degree of brackish aquatic \\
\hline AC.cq.7 & $\begin{array}{l}\text { The number (or percentage) canals } \\
\text { dredged }\end{array}$ & AC.cd.7 & Per capita income \\
\hline AC.cq. 8 & $\begin{array}{l}\text { Distance from the considered region to } \\
\text { the nearest regulatory works }\end{array}$ & AC.cd.8 & Education index \\
\hline AC.cq. 9 & $\begin{array}{l}\text { Proportion of health workers / } \\
\text { population }\end{array}$ & AC.cd.9 & Proportion of employed workers \\
\hline AC.cq.10 & The proportion of teachers / pupils & & \\
\hline
\end{tabular}




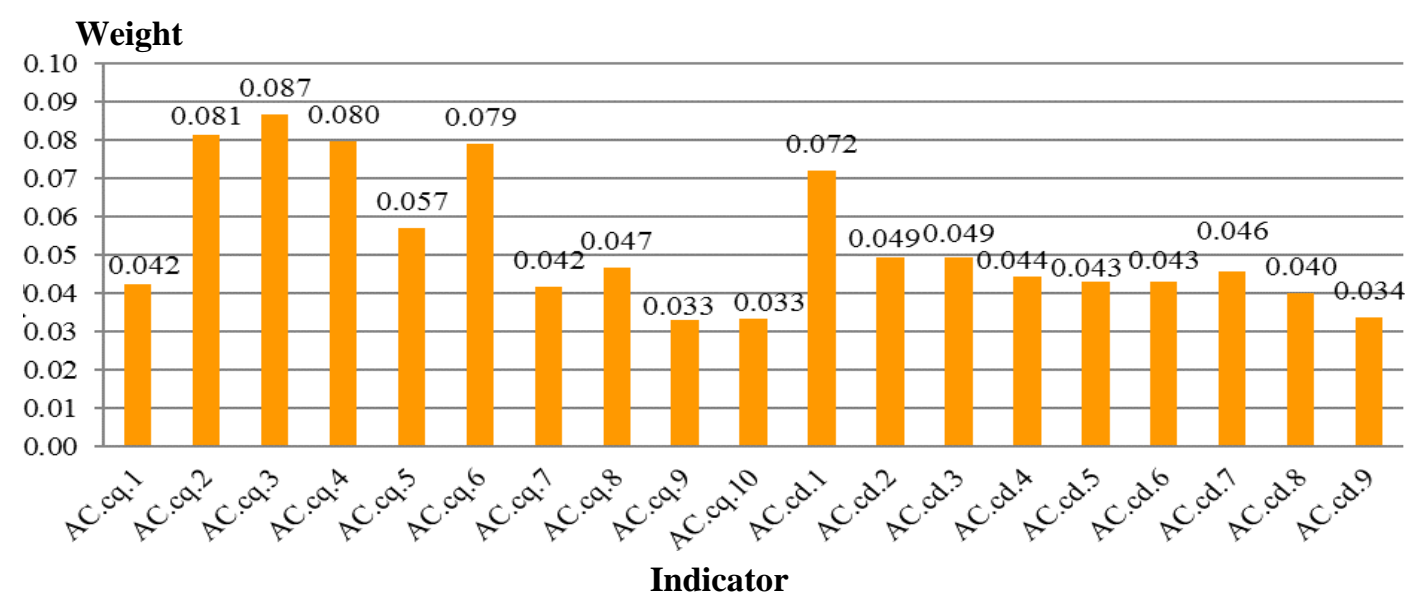

Fig. 1. Priority weight of AC indicators

\section{Evaluation of AC to SI in the context of CC}

Process of AC calculation was initiated by standardizing collected data (0-100), multiplying to the priority weight (Fig. 1), totaling and then decentralizing into 4 different levels (Table 1). It was used as a basis for comparing and evaluating the AC values among investigated communes/ wards.

\section{Spatial distribution of AC index}

Nhon Trach district had the highest AC to SI (46.21 points in 2014) with $50 \%$ of communes having the medium-low AC index and the rest 50 $\%$ at the medium-high level in 2014. By 2030, $\mathrm{AC}$ of all communes in this district would be at the medium-high level, especially Dai Phuoc, Phu Huu, Phu Hoi, Tan Long, Long Tho, and Phu Dong communes.

Long Thanh district was ranked 2 with $\mathrm{AC}$ index of 35.82 points in 2014. During the period from 2014 to 2020, all communes/towns would have the medium-low AC. By 2030, there would be 3 communes/towns having the medium-high
AC: Binh An, Long Phuoc communes and Long Thanh town.

Bien Hoa City has the lowest $\mathrm{AC}$ in the 03 investigated districts (35.72 points - 2014). All communes/wards had $\mathrm{AC}$ at the medium-low level in 2014. There would be only one and three communes/wards having the medium-high AC by 2020 (Hiep Hoa) and 2030 (Hiep Hoa, Trang Dai, and Long Binh Tan), respectively.

Overall, the AC indices of Nhon Trach district are higher than those of Long Thanh district and Bien Hoa city. However, the current $\mathrm{AC}$ indices were relatively low, thus needing more efforts to overcome these defects and promote the advantages in the adaptation to the salinization.

\section{Distribution of AC over time}

In 2014, there were 51 communes/wards having the the medium-low $\mathrm{AC}(89.5 \%)$, the rest (6 communes/wards) achieved the medium-high AC. Notably, all communes/wards in Bien Hoa city and Long Thanh district got the the mediumlow AC. 


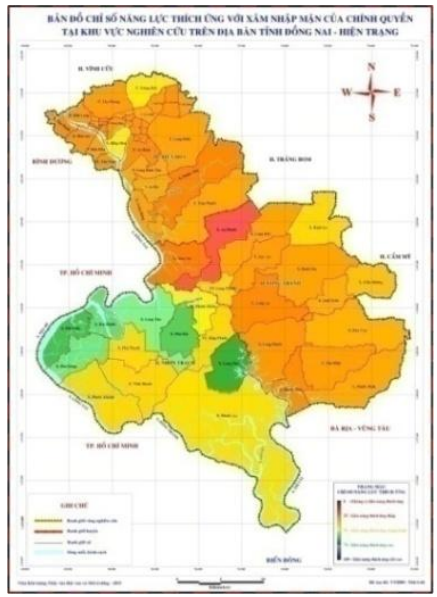

(A)

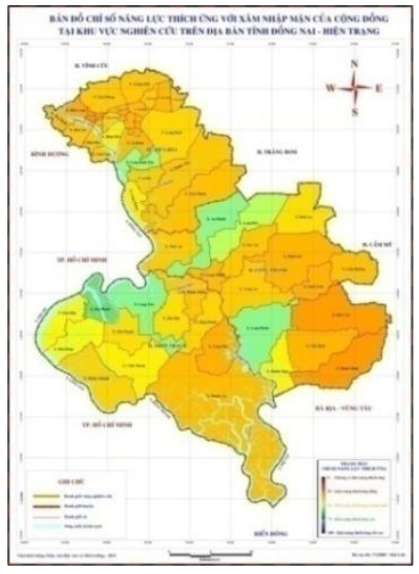

(B)

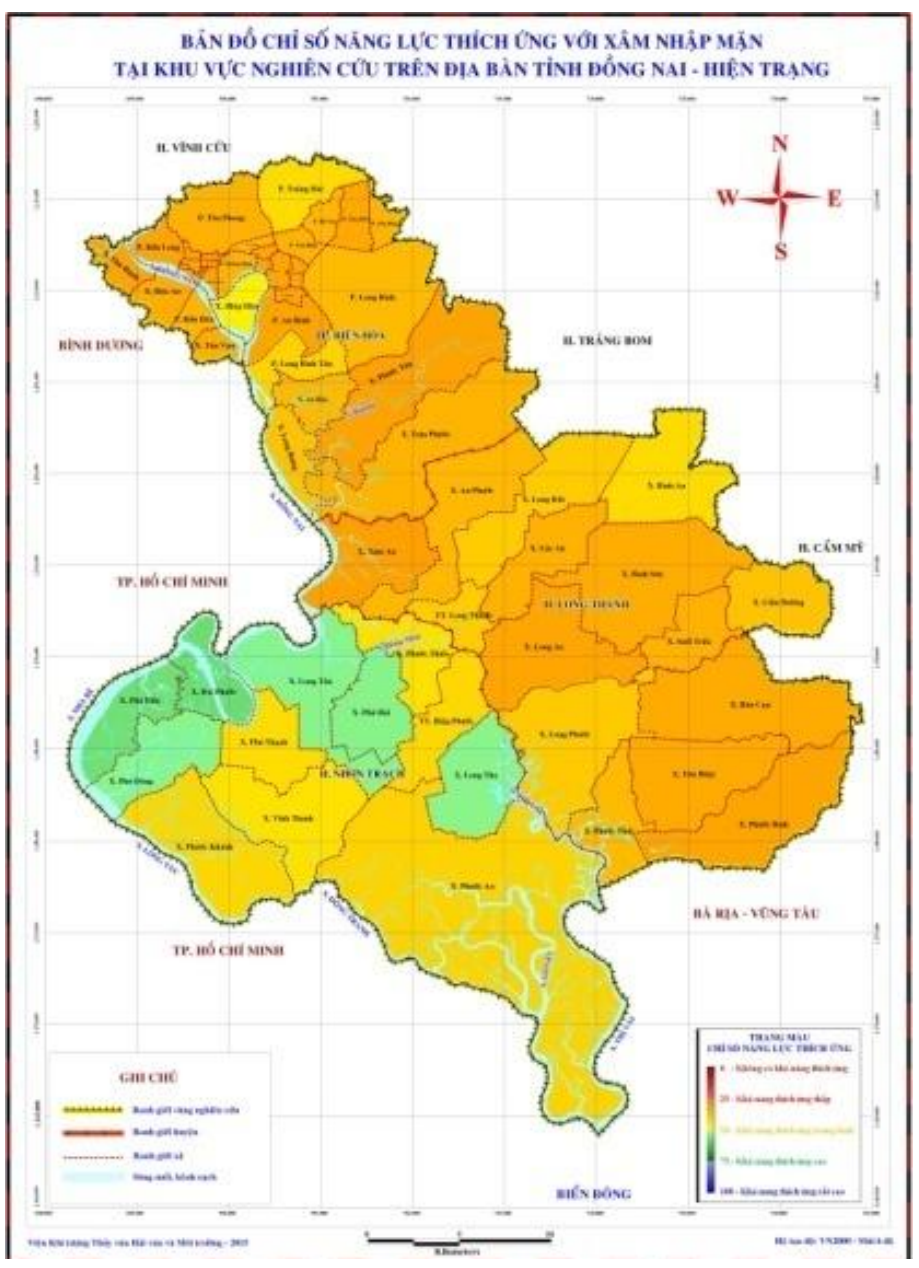

(C)

Fig. 2. Map of adaptive capacity to salinization in 2014:

(A) AC-government, (B) AC-communities, (C) synthetic AC

At Bien Hoa city, communes/wards had the strength of $\mathrm{AC}$ as Hiep Hoa, Trang Dai, Long Binh Tan, etc. In addition to the advantage of people's income, the percentage of workers with employment, ability of access to information when incidents occur, etc., the low AC could be resulted from both local government and communities (Fig. 2A, B). In fact, the current situation and the impact of SI in Bien Hoa City have not yet been serious and clear, especially when the local agricultural development is not priority, the relevant indicators are thus less of concern.
Similar to Bien Hoa city, all communes/towns in Long Thanh district had the medium-low AC, notably AC indices of Loc An, Binh Son, Bau, Tan Hiep, Binh Phuoc, Long An, Tam An communes were below 35 .

Calculating results for 2014 showed $50 \%$ of communes/towns in Nhon Trach district having the medium-low $\mathrm{AC}$ and the rest being at the medium-high level; some of them were Dai Phuoc, Phu Huu, Phu Hoi, Long Tan and Phu Dong, Long Tho communes. Notably, Dai Phuoc had the highest AC both in the district and the surveyed area ( $\mathrm{AC}=57.32$ in 2014), followed by 
Phu Huu commune ( $\mathrm{AC}=56.67$ in 2014). In general, a number of features strengthening AC to SI in Nhon Trach district included the high density of dredged canals, good ability of clean water storage, budget allocation for coping with SI, the highest percentage of agricultural land supported by saline works, etc.

By 2020, the AC index would be increased due to the improvement of awareness of SI and $\mathrm{CC}$, increase in ability to access information, and income, etc. (Fig. 3C). However, the AC is still low: in 57 investigated wards, there are only 7 communes with the medium-high AC (12.3\%) and the rest with the medium-low $\mathrm{AC}(87.7 \%)$. AC maps in 2020 for each object (Fig. 3A, B) showed that $\mathrm{AC}$ of the local governments would be almost at the medium-low level (51/57 communes/wards) while their roles are more important than those of communities in adapting to SI. Nhon Trach district maintains the AC to SI higher than that of Bien Hoa city and Long Thanh district with $50 \%$ of communes/towns having the medium-low $\mathrm{AC}$ and the rest having the medium-high $\mathrm{AC}$, in which, dominant communes still are Dai Phuoc, Phu Huu, Phu Hoi, Long Tan, Phu Dong, and Long Tho.

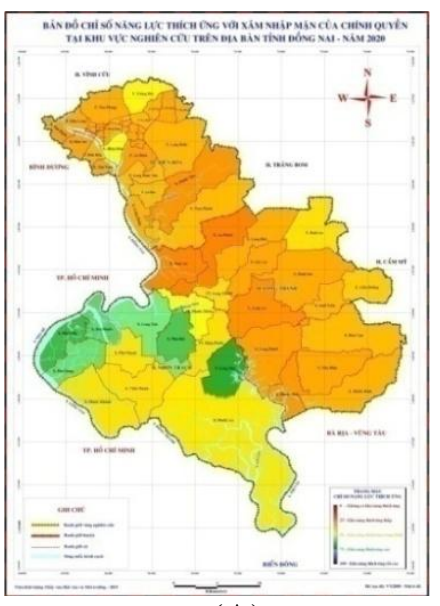

(A)

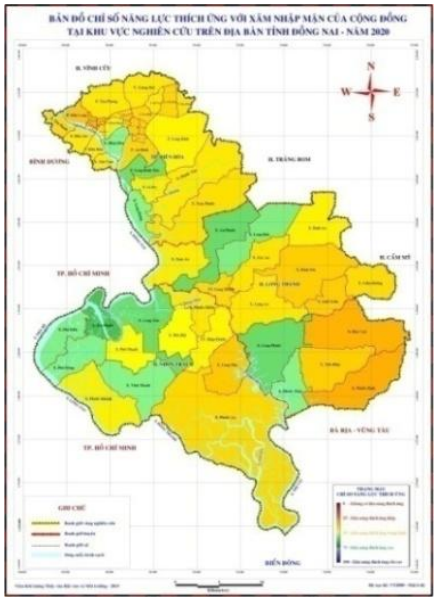

(B)

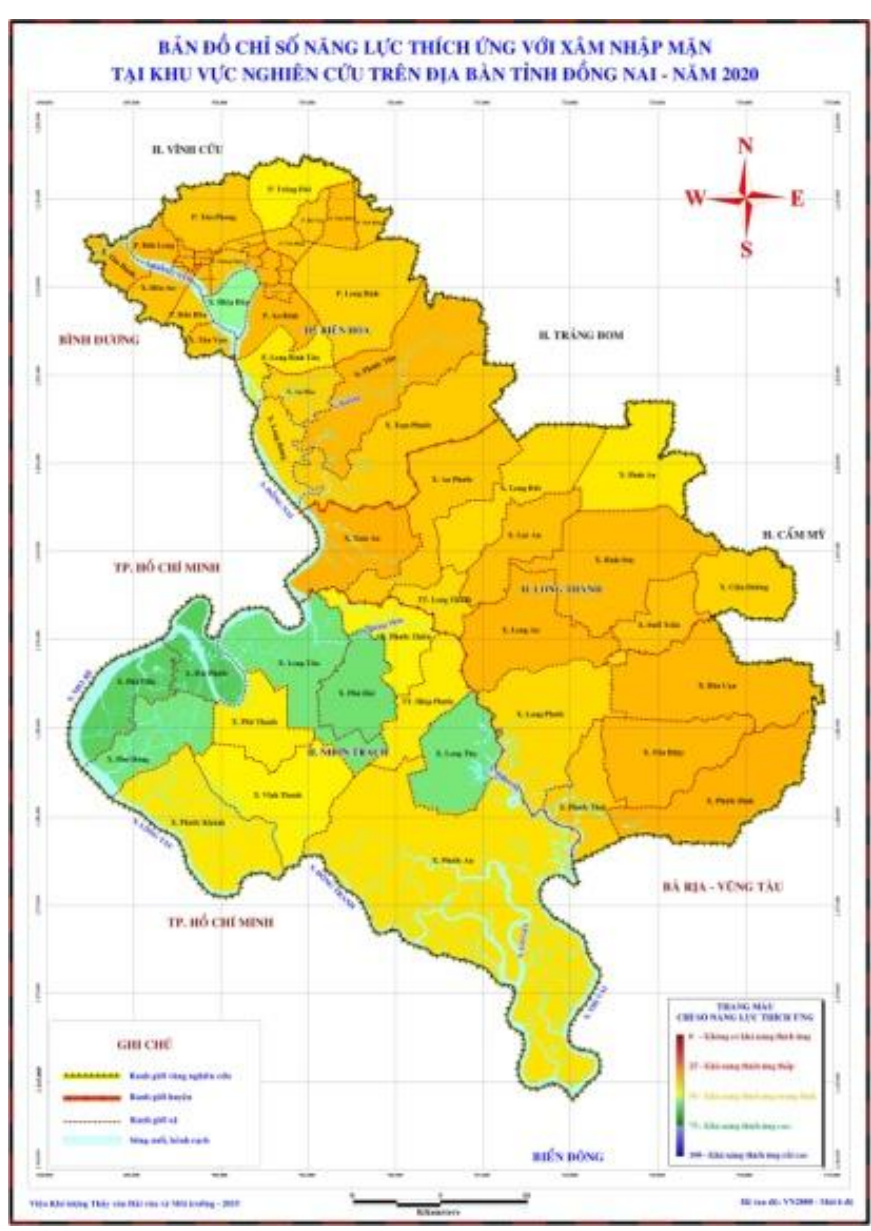

(C)

Fig. 3. Maps of adaptive capacity to salinization in 2020

(A) AC-government, (B) AC-communities, (C) synthetic AC

\section{Trang 232}


By 2030, results showed 18 communes having the medium-high AC (12 in Nhon Trach district, 3 in Bien Hoa city and 3 in Long Thanh district) - accounted for $31.6 \%, \quad 39$ communes/wards getting the medium AC accounted for $68.4 \%$. AC-communities are almost at the medium-high level (53/57 communes/wards) while the medium-low $\mathrm{AC}$ belongs to local government (48/57 communes/wards) (Fig. 3A, B). Similar to the period of 2014 - 2020, Nhon Trach district remains dominant in adaptating SI with 12/12 communes/towns having the medium-high AC (Fig. 2C) while the corresponding figures are 3/15 and 3/30 in Long Thanh and Bien Hoa, respectively.

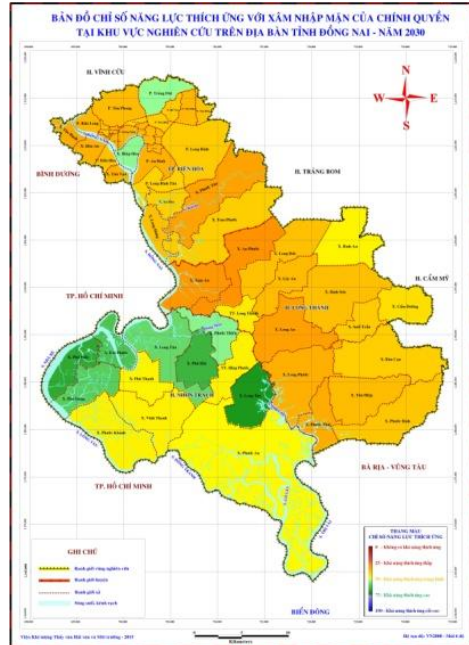

(A)

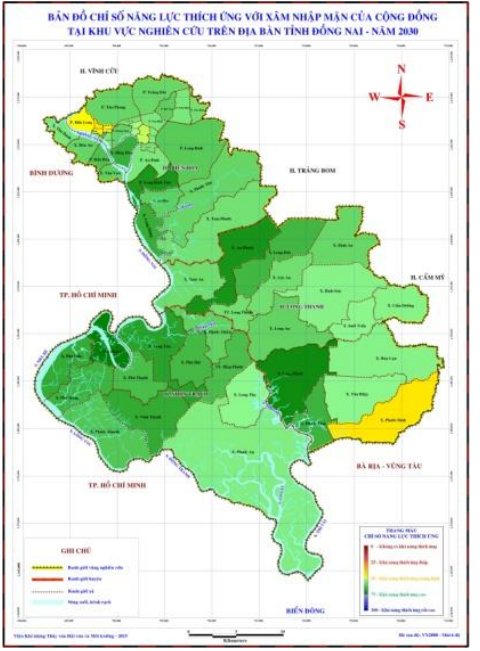

(B)

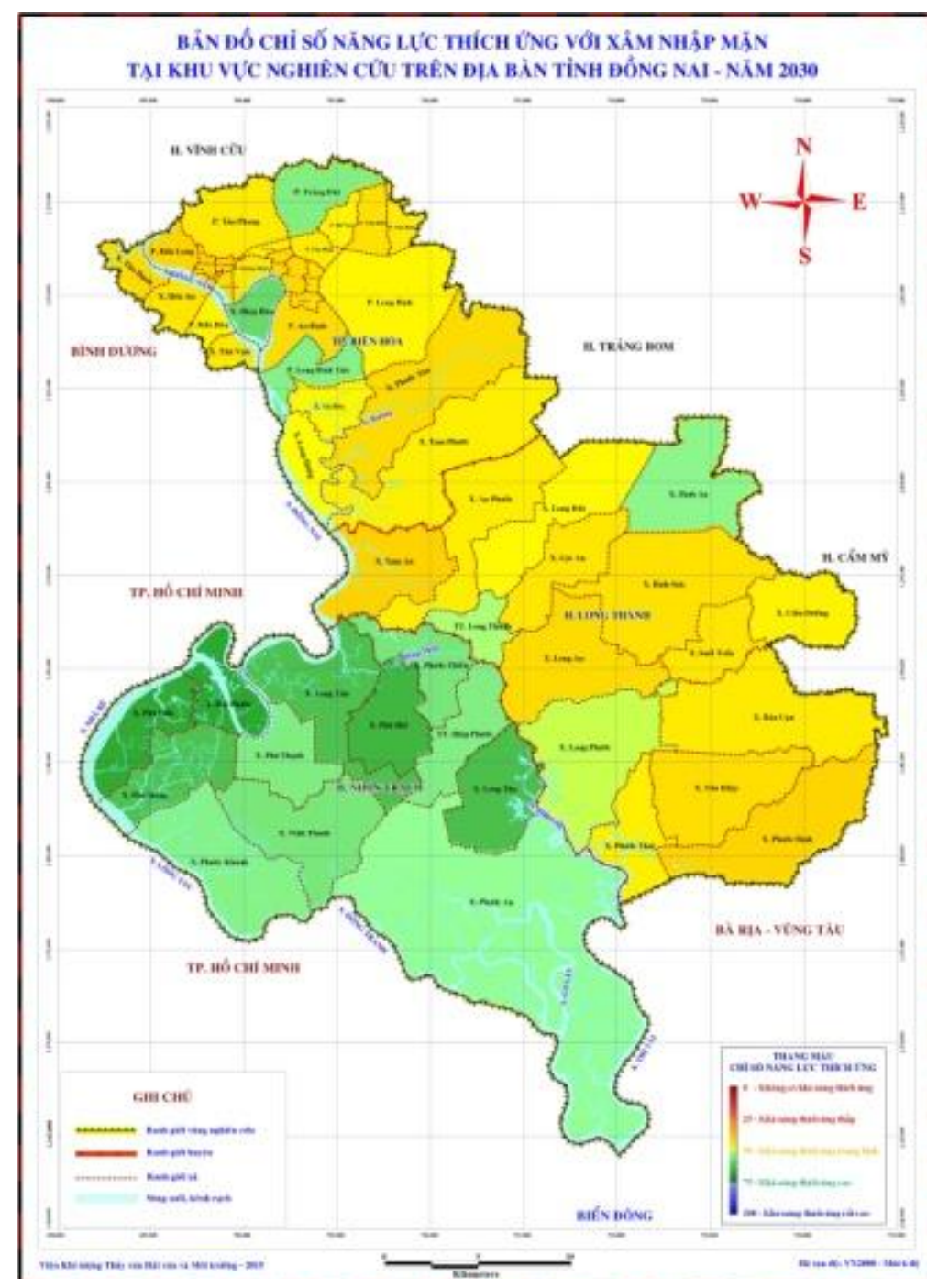

(C)

Fig. 4. Maps of adaptive capacity to salinization in 2030

(A) AC-government, (B) AC-communities, (C) synthetic AC 


\section{CONCLUSION}

Based on the AC indicators to SI, this work gathered and standardized data, interviewed experts, and calculated AC index. Results showed that Nhon Trach district has the highest AC, followed by Bien Hoa city and Long Thanh district. AC indices at the locals are gradually improved from 2014 to 2020 and 2030 as follows: Bien Hoa (37.2, 41.5, and 48.5), Long Thanh $(36.5,39.4$ and 46.7) and Nhon Trach (47, 50.2 and 57.4). In 2014, 51/57 investigated communes/wards had the medium-high AC (89.5 $\%$ ); by 2020 and 2030, this ratio would be decreased to $87.7 \%$ and $59.6 \%$, respectively. Accordingly, the ratios of the communes/wards with the medium-high $\mathrm{AC}$ would be increased from $10.5 \%$ in 2014 and to $12.3 \%, 40.4 \%$ in 2020 and 2030, respectively. By 2030, there would be 23 communes (40.4\%) having the medium-high AC to SI, including 12 communes/towns in Nhon Trach, 7 communes/wards in Bien Hoa and 4 communes in Long Thanh.

Although AC is increased over time but the values are still relatively low. This requiries appropriate solutions to improve the current defects and the adaptive capacity to SI for the saltwater intrusion in the local, especially in the context of climate change.

\section{Đánh giá năng lực thích ứng với xâm nhập mặn trên địa bàn tỉnh Đồng Nai đến năm 2030}

- Lê Ngọc Tuấn

Trường Đại học Khoa học Tự nhiên, ĐHQG-HCM

- Vũ Thị Ngọc Mỹ

Viện Khí tượng Thủy văn Hải văn và Môi trường

\section{TÓM TẮT}

Nghiên cưu này thục hiện đánh giá năng lục thich ưng $(A C)$ với xâm nhập mặn (XNM) tại tỉnh Đồng Nai đến năm 2030. Theo đó, phạm vi nghiên cứu là 57 phuoòng xã trên địa bàn Thành phố Biên Hòa , Huyện Long Thành và Nhơn Trach - nhũng noi đang xảy ra và có nguy co XNM.

Kết quả tính toán cho thấy năm 2014, gần 90 \% xã/phưòng có múc năng lực thich úng trung bình thấp, tập trung chủ yếu ở TP Biên Hòa (30), H. Long Thành (15) và H. Nhơn Trạch (6). Dư báo đến năm 2020 và 2030, AC tại các địa phuơng gia tăng so với hiện tại. Tỷ lệ xã/phương có AC trung bình thấp giảm còn $88 \%$ và hon 68
\% vào năm 2020 và 2030. Các chi thị AC đáng quan tâm cải thiện trên địa bàn bao gồm: tài chính (ngân sách, GDP), chính sách (hố trợ người dân úng phó với XNM và BĐKH), canh tác nông nghiệp (giống và diện tích cây trồng chịu mặn), thủy sản (giống và diện tích thủy sản nước lộ/mặn), công trình thủy lợi (tuoơi tiêu, ngăn mặn), trũ nước sinh hoạt, y tế và giáo ducc.

Nhìn chung, giai đoạn 2014-2030, AC của địa bàn nghiên cứu tăng dần qua các năm; tuy nhiên, đa phần chi dùng lại ở mức trung bình thấp. Đây là thách thức cho chính quyền cũng nhu cộng đồng dân cu trong công tác úng phó với XNM và bối cảnh BĐKH ngày càng gia tăng.

Tù khóa: xâm nhập mặn, năng lực thích ưng, biến đổi khí hậu

\section{Trang 234}




\section{REFERENCES}

[1]. V.D. Hoang, H.T. Tran, One-dimensional and two-dimensional hydrodynamic modeling for salinization downstream forecast in Ma River, Journal of Hydrometeorology, 645, 1-6 (2014).

[2]. Q.D. Tran, H.T. Nguyen, L. Kanchit, Simulation of saltwater intrusion in Mekong Delta under the impacts of sea level rise and upstream flow decline, Journal of Science, 21b, 141-150 (2012).

[3]. T.B. Nguyen, H. Lam, S.P. Thach, Vulnerability assessment with involvement: Salinization in the Mekong Delta, Journal of Science, 24b, 229-239 (2012).

[4]. T.D. Vo, Assessing vulnerability due to saltwater intrusion to agriculture in coastal area in Tra Vinh, Journal of Science and Technology Tra Vinh province, 02, 24-33 (2014).

[5]. H.H. Vu, H.D. Luong, Research, forecast trend saltwater intrusion due to sea level rise for estuaries on North Coast, Journal of Water resources and Environmental Engineering, 27, 66-78 (2009).

[6]. Mo, Phuoc Hoa, Dau Tieng to Dongnai Saigon river downstream, State Scientific Research (1995).

[7]. T.L. Do et al, The study on integrated using the water in Dau Tieng reservoir as supplement of Phuoc Hoa reservoir, Southern Institute of Water Resources Research (2005).

[8]. M.T. Lam, Study and proposed feasible and suitable model for organization to coordinate the implementation of environmental protection projects in Dong Nai river basin, Department of Natural Resource and Environment, Ho Chi Minh City (2006).
[9]. V.N. Dau, Computing saltwater intrusion in Dong Nai river basin, Journal of Geology (2007).

http://www.idm.gov.vn/nguon_luc/Xuat_b an/2007/A301/a76.htm, assessed on 7 Sep 2016

[10]. W.N. Adger, P.M. Kelly, Social vulnerability to climate change and the architecture of entitlements, Mitigation and Adaptation Strategies for Global Change (1999).

[11]. B.L. Preston, D. Abbs et al, Spatial Approaches for Assessing Vulnerability and Consequences in Climate Change Assessments, Paper presented at the Proceedings of MODSIM 2007: International Congress on Modelling and Simulation, Christchurch, NZ (2007).

[12]. World Bank - Economics of adaptation to climate change in Vietnam's aquaculture sector (2010).

[13]. T.S Nguyen, T.V. Can, The methods of assessing vulnerability - Theory and Practice - Part 1: Applicability in assessing vulnerability to floods in Central of Vietnam, Journal of Science - Vietnam National University - Hanoi: Natural Sciences and Technology, 28, 3S, 115-122 (2012).

[14]. A.A. Yusuf, H. Francisco, Climate Change Vulnerability Mapping for Southeast Asia, Published by EEPSEA (2009).

[15]. IPCC WGII - Climate Change 2001: Impacts, adaptation, and vulnerability. Contribution of Working Group II to the Third Assessment Report of the Intergovernmental Panel on Climate Change. Cambridge University Press, Cambridge, United Kingdom and New York, NY, USA, 365-388 (2001). 